\title{
ORTODONTINIO GYDYMO POVEIKIS DANTENŲ RECESIJOS FORMAVIMUISI
}

\author{
Dominyka Grinkevičien $\dot{e}^{1}$, Urtė Marija Sakalauskaitė ${ }^{2}$ Austė Antipovienė $\dot{3}^{3}$ \\ ${ }^{I}$ Šeimos klinika ,MediCA “, ${ }^{2,3}$ Lietuvos sveikatos moksly universiteto Medicinos akademija, \\ Odontologijos fakultetas, Dantu ir burnos ligu klinika
}

Raktažodžiai: ortodontinis gydymas, dantenų recesija.

\begin{abstract}
Santrauka
Dantenų recesija - viena dažniausių ortodontinio gydymo komplikacijų. Dantenų recesijos atsiradimo priežastys nèra galutinai aiškios. Manoma, kad ji gali formuotis dèl pablogejjusios burnos higienos gydymo metu, ortodontiniu judesių metu sukuriamos jègos. Vieni autoriai nurodo, jog danties judesys iš alveolinès ataugos kaulo yra dantenų atsitraukimą sukeliantis veiksnys, kiti šios asociacijos nenurodo. Darbo tikslas - išsiaiškinti ir ịvertinti esamus įrodymus, pagrindžiančius ortodontinio gydymo ir dantenų recesijų sąveiką; išanalizuoti naujausią mokslinę literatūrą apie dantenų recesijos atsiradimą individams, praejus panašiam laiko tarpui po ortodontinio gydymo pabaigos. Literatūros apžvalgai taikyta PRISMA atrankos sistema. Elektroninè literatūros apžvalga atlikta naudojant PubMed ir Cochrane duomenų bazes, remiantis atrankos kriterijais. İ literatūros apžvalgą itrauktos 3 publikacijos, kurios atitiko atrankos kriterijus. Išanalizuotas dantenų recesijų išsivystymo dažnis, praèjus 5-7 metams po ortodontinio gydymo pabaigos. Literatūros apžvalgos duomenimis, dantenų recesijos formavimuisi svarbus laiko tarpas, praejjęs po ortodontinio gydymo: didejjant laiko tarpsniui po gydymo, didèja dantenų recesijos tikimybè. Kai kurių autorių nuomone, dantų recesijos eiga gali būti siejama su paciento lytimi ir amžiumi ortodontinio gydymo metu.
\end{abstract}

\section{Ivadas}

Ortodontinio gydymo metu siekiama sukurti sveiką ir stabilią funkcinę okliuziją, užtikrinant gerą estetiką bei harmoningą veido išvaizdą [1]. Gydymas užkerta kelią dantų dilimui ir smilkinkaulio-apatinio žandikaulio sąnario sutrikimams progresuoti, pagerina burnos higieną, o kartu dantų ir dantenų būklę, patobulina šypsenos estetinị vaizdą [2]. Nepaisant daugybės ortodontinio gydymo privalumų, yra keletas rizikos veiksnių, kurie gali komplikuoti gydymą [3]. Komplikacijų pasireiškimas priklauso nuo pasirinktos ortodontinio gydymo technikos, paciento bendrosios ir burnos ertmès būklių bei higienos ịpročių [4].

Viena dažniausiai pasitaikančių komplikacijų - dantenų recesija. Tai būklè, kai dèl dantenų krašto pasislinkimo apikaline kryptimi link cemento-emalio jungties, apsinuogina danties šaknies paviršius [5]. Recesija dažniau pasireiškia apatiniame žandikaulyje, nei viršutiniame, gali būti vietinè arba generalizuota, apimti vieną arba kelis danties paviršius [6]. Tokie pokyčiai dažniausiai sukelia dantų jautrumą, kaklelinès vainiko dalies nusidèvèjimą, eroziją bei padidèjusi dantų paslankumą. Tai lemia estetines, funkcines bei psichologines problemas [7]. Mokslinejje literatūroje nèra bendros nuomonès, kas lemia recesijų atsiradimą ortodontinio gydymo eigoje: pablogèjusi burnos higiena ar jègos, sukuriamos ortodontinių judesių metu. Kadangi pažeidimai dažnai atsiranda estetinėje zonoje, jie ženkliai pablogina gydymo rezultatą.

B. Melsen su bendraautoriais [8] atliktame tyrime pastebejjo, jog recesijų formavimasis po ortodontinio gydymo padidejo nuo 21 iki 35 proc., o tiriant ortodontinio gydymo pasekmes individams, kuriems buvo diagnozuotas atviras sąkandis, recesijų atsiradimas siekè net 75 proc. visų tiriamujjų [9]. Tiriant jauno amžiaus individus nustatyta, jog ortodontinis gydymas nèra pagrindinè recesijų atsiradimo priežastis [10].

Yra nuomonių, jog ortodontinis gydymas gali padèti išvengti recesijų atsiradimo arba prisidèti prie jų gydymo, kartu taikant ir periodontologini gydymą [6]. 2016 metais Amerikos ortodontų asociacija šị teiginį patvirtino [11]. Pastaraisiais metais atlikta nemažai tyrimų, nagrinejjančių galimai neigiamą ortodontinio gydymo poveikį dantenų recesijų formavimuisi, tačiau prie bendros nuomonès neprieita. Viena iš priežasčių gali būti ta, jog buvo tiriami skirtingo 
amžiaus individai, o recesijų vertinimas atliekamas neatsižvelgiant ị laiko tarpą, praejjusị nuo gydymo pabaigos.

Tyrimo tikslas - ištirti šiuolaikinę turimą informaciją apie dantenų recesijų formavimąsi panašaus amžiaus individams, analizuojant tik tuos tyrimus, kuriuose recesijų vertinimas atliekamas praèjus panašiam laiko tarpui po ortodontinio gydymo pabaigos.

\section{Medžiaga ir metodai}

Mokslinès literatūros apžvalga atlikta taikant PRISMA atrankos kriterijus. Mokslinių publikacijų ieškota PubMed, Cochrane duomenų bazèse. Prieš pradedant mokslinès literatūros analizę, trys tyrejjai susipažino su straipsnių apžvalgos protokolu, itraukimo bei atmetimo kriterijais (1 lentelè). Mokslinių publikacijų paieška rèmèsi raktiniais žodžiais ir jų junginiais. Apie straipsnių tinkamumą, remdamiesi atrankos kriterijais, sprendè trys tyrèjai, o kilę nesutarimai išspręsti diskutuojant. Paieška pradèta $2019 \mathrm{~m}$. rugsèjo 3 d., baigta gruodžio 15 dieną ( 2 lentelè).

\section{Rezultatai}

Šioje sisteminėje apžvalgoje išanalizuoti 3 visateksčiai straipsniai [12-14]. Jų analizès rezultatai pateikiami 3 lentelèje.

A. Renkema su bendraautoriais ištyrẻ 302 individus, atitinkančius šiuos kriterijus: 1) gydyti

1 lentelė. Mokslinių straipsnių atrankos kriterijai

\begin{tabular}{|l|l|}
\hline $\begin{array}{l}\text { Straipsnių įtraukimo } \\
\text { kriterijai }\end{array}$ & $\begin{array}{l}\text { Straipsnių atmetimo } \\
\text { kriterijai }\end{array}$ \\
\hline $\begin{array}{l}\text { Straipsniai ne senesni } \\
\text { nei 6 metų }\end{array}$ & $\begin{array}{l}\text { Straipsniai senesni nei 6 } \\
\text { metų }\end{array}$ \\
\hline Straipsniai anglų kalba & $\begin{array}{l}\text { Studijos, atliktos su indi- } \\
\text { vidais, turinčiais genetinių } \\
\text { sindromų }\end{array}$ \\
\hline $\begin{array}{l}\text { Tyrimai, atlikti su žmo- } \\
\text { nėmis }\end{array}$ & Atvejo aprašymai \\
\hline $\begin{array}{l}\text { Tyrimai, tiriantys rece- } \\
\text { sijų susiformavimą po } \\
\text { ortodontinio gydymo }\end{array}$ & Santraukos \\
\hline $\begin{array}{l}\text { Tiriamujų amžiaus vi- } \\
\text { durkis 15-18 metų }\end{array}$ & $\begin{array}{l}\text { Studijos, atliktos su gyvū- } \\
\text { nais }\end{array}$ \\
\hline $\begin{array}{l}\text { Tyrimai, kuriuose rece- } \\
\text { sijų vertinimas atliktas } \\
\text { praejjus 5-7 metams po } \\
\text { ortodontinio gydymo }\end{array}$ & Literatūros apžvalgos \\
\hline
\end{tabular}

tik fiksuotais aparatais; 2) iškart po gydymo pabaigos pritvirtinti fiksuoti reteineriai; 3) netaikytas pakartotinis ortodontinis gydymas; 4) išlikę geros kokybės dantų modeliai prieš gydymą, iškart po gydymo, po 2 ir 5 metų po gydymo. Tiriamujų sąkandžio tipas prieš gydymą buvo: Angle I - 51, Angle II - 247, Angle III - 4. Vidutinè gydymo trukmė - 2,8 metų. 195 tiriamiesiems taikytas neekstrakcinis, o 107 - ekstrakcinis gydymo metodas. Tyrime buvo matuojami kraštinių dantenų pokyčiai labialinejje dantų puseje. Recesija registruota, esant atsidengusiai cemento-emalio jungčiai. Tyrime buvo pastebėtas reikšmingas recesijų didèjimas, didejant laiko tèkmei nuo gydymo pabaigos. Gydymo pradžioje recesijų skaičius siekė 7 proc., po 2 metų -20 proc., po 5 metų -38 procentus. Autoriai pastebejjo, jog recesijų formavimuisi svarbu amžius: individams, kuriems gydymo pabaigoje buvo daugiau nei 16 metų, recesijų užregistruota reikšmingai dažniau $(p<0,05)$. Nebuvo pastebėta teigiamos koreliacijos tarp recesijų bei lyties, retainerio ar pasirinkto ekstrakcinio ar neekstrakcinio gydymo metodo [13].

J. Juloski su bendraautoriais atliktame tyrime buvo ištirti 96 individai, atitinkantys kriterijus: 1) gydyti tik fiksuotais aparatais; 2) gydymo pradètas iki 18 metų; 3) išlikę geros kokybès dantų modeliai prieš gydymą ar 5 metus po gydymo. 48 pritvirtintas fiksuotas reteineris po gydymo pabaigos, 48 retencijos netaikytos. Sudaryta kontroliné 48 pacientu grupé, kuriems ortodontinis gydymas nebuvo taikytas. Tyrime išmatuoti visų apatinio žandikaulio kandžių ir ilčių kraštinių dantenų pokyčiai. Recesija fiksuota, esant atsidengusiai cemento-emalio jungčiai. Registruota, ar tiriamosios grupès dalyviams yra konkrementų apatinio

2 lentelè. Straipsnių atrankos procesas

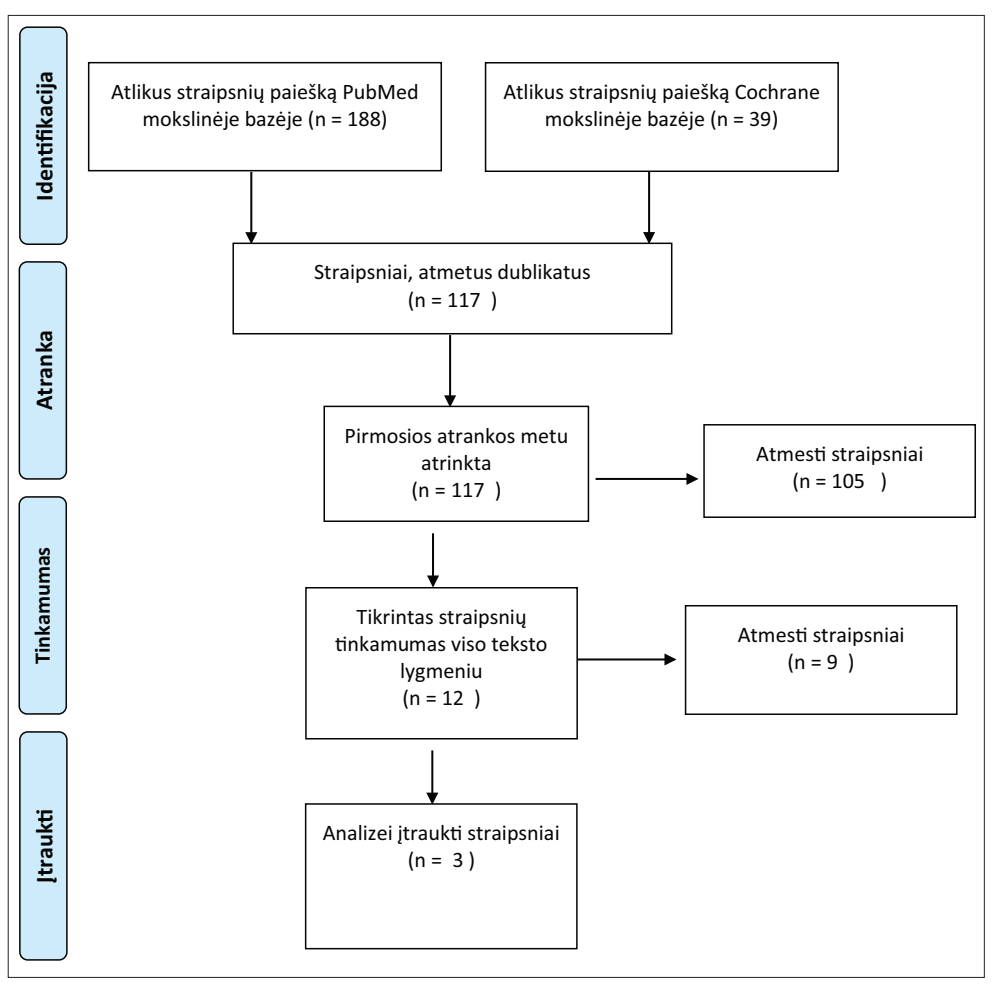


žandikaulio priekinių dantų srityje. Tyrime nustatyta, jog recesijų skaičius buvo reikšmingai didesnis ir tiriamojoje, ir kontrolinèje grupèse, lyginant prieš gydymą ir 5 metai po gydymo, tačiau reikšmingo skirtumo tarp šių grupių nustatyta nebuvo $(\mathrm{P}>0,05)$. Pastebèta, jog dèvejję fiksuotą reteineri individai turejo reikšmingai daugiau konkrementų apatinio žandikaulio kandžių srityje, nei tie, kuriems retencija po gydymo taikyta nebuvo $(\mathrm{P}<0,05)$. Autoriai pateikè išvadas, jog recesijos nesusijusios su ortodontiniu gydymu, retencijos pasirinkimu, amžiumi, lytimi bei sąkandžio būkle prieš ortodontini gydymą [14].

F. Pernet su bendraautoriais ištyrè 126 individụ duomenis. Pagal amžių tiriamieji buvo suskirstyti ị dvi grupes: 1) iki 20 metu -101;2) vyresni nei 20 metų -26. Duomenys buvo registruojami prieš gydymą, iškart po gydymo, 7 metai po gydymo. Visiems tiriamiesiems buvo taikomi fiksuoti reteineriai iškart baigus gydymą. Vidutinè gydymo trukmé siekè 3,9 metu jaunesniajai grupei bei 2,8 metu vyresniajai grupei. Gydymo pabaigoje pirmosios grupès amžiaus vidurkis buvo 15 metų, antrosios 35 metai. Tyrime buvo išmatuoti 506 apatinio žandikaulio kandžių kraštinių dantenų pokyčiai bukalinèje ir labialinèje pusèse. Esant recesijai, alveolinès keteros storis vertinamas $2 \mathrm{~mm}$ nuo cemento-emalio jungties. Pirmajai grupei tiriamujų gydymo pradžioje recesijų skaičius lingvaliniame ir bukaliniame paviršiuose siekè po1 proc., gydymo pabaigoje recesijų skaičius bukaliniame paviršiuje

3 lentelè. Straipsnių analizès rezultatai

\begin{tabular}{|c|c|c|c|c|c|c|c|c|c|c|}
\hline Autoriai & $\begin{array}{c}\text { Publi- } \\
\text { kacijos } \\
\text { metai }\end{array}$ & Kalba & $\begin{array}{c}\text { Tyrimo } \\
\text { imtis }\end{array}$ & $\begin{array}{l}\text { Vidutinis } \\
\text { tiriamụjų } \\
\text { amžius }\end{array}$ & $\begin{array}{l}\text { Tiria- } \\
\text { mujju } \\
\text { lytis } \\
\text { (M/V) }\end{array}$ & \begin{tabular}{|c|} 
Recesiju \\
vertinimo \\
laikas (po \\
ortodontinio \\
gydymo)
\end{tabular} & $\begin{array}{l}\text { Vertinimo } \\
\text { metodas }\end{array}$ & $\begin{array}{l}\text { Kon- } \\
\text { trolinè } \\
\text { grupé }\end{array}$ & $\begin{array}{l}\text { Taikytas } \\
\text { orto- } \\
\text { dontinis } \\
\text { gydymas }\end{array}$ & Rezultatai \\
\hline \begin{tabular}{|l} 
A. Ren- \\
kema ir kt. \\
{$[13]$}
\end{tabular} & 2013 & Anglų & 302 & $\begin{array}{c}16 \\
(12-35)\end{array}$ & $185 / 117$ & 5 metai & $\begin{array}{c}\text { Dantul } \\
\text { modeliai }\end{array}$ & Netaikyta & $\begin{array}{l}\text { Fiksuoti } \\
\text { aparatai }\end{array}$ & $\begin{array}{l}\text { Recesiju } \\
\text { skaičius } \\
\text { reikšmingai } \\
\text { padidejo nuo } \\
7 \% \text { iki } 38 \% .\end{array}$ \\
\hline \begin{tabular}{|l|} 
J.Juloski ir \\
kt. [14]
\end{tabular} & 2017 & Anglų & 144 & $\begin{array}{c}16 \\
(11-22)\end{array}$ & $47 / 49$ & 5 metai & $\begin{array}{c}\text { Dantu } \\
\text { modeliai, } \\
\text { rentgeno } \\
\text { nuotrau- } \\
\text { kos, } \\
\text { intraora- } \\
\text { linès nuo- } \\
\text { traukos }\end{array}$ & $\begin{array}{l}\text { Taikyta } \\
(\mathrm{n}=48)\end{array}$ & $\begin{array}{l}\text { Fiksuoti } \\
\text { aparatai }\end{array}$ & $\begin{array}{c}\text { Abiejose } \\
\text { grupèse - } \\
\text { reikšmingas } \\
\text { recesiju } \\
\text { padidèjimas. } \\
\text { Skirtumo } \\
\text { tarp grupių } \\
\text { nestebima. }\end{array}$ \\
\hline $\begin{array}{l}\text { F. Pernet ir } \\
\text { kt. [12] }\end{array}$ & 2019 & Anglų & 126 & $\begin{array}{c}15 \\
(12-19)\end{array}$ & $72 / 52$ & 7 metai & $\begin{array}{c}\text { Dantų } \\
\text { modeliai, } \\
\text { rentgeno } \\
\text { nuotrau- } \\
\text { kos }\end{array}$ & Netaikyta & Nenurodyta & $\begin{array}{c}\text { Recesiju } \\
\text { skaičius } \\
\text { reikšmingai } \\
\text { padidejo } \\
\text { nuo } 1 \% \text { iki } \\
16,1 \% \text {. }\end{array}$ \\
\hline
\end{tabular}

išaugo iki 4 proc., 7 metai po gydymo recesijų užregistruota 16,1 proc. bukaliniame ir 7,9 proc. lingvaliniame paviršiuose. Antrosios grupès tiriamiesiems gydymo pradžioje recesijų skaičius bukaliniame paviršiuje buvo 15,4 proc., ligvaliniame 11,5 procentų. Gydymo pabaigoje skaičius išaugo iki 30,8 procentų. Vertinant 7 metai po gydymo, užregistruota 50 proc. recesijų bukaliniame paviršiuje bei 42 proc. recerecesijų formavimasis yra statistiškai reikšmingai susijęs su amžiumi bei lytimi $(\mathrm{p}<0,05)[12]$.

\section{Diskusija}

Šios literatūros apžvalgos tikslas buvo išsiaiškinti dantenų recesijas predisponuojančius veiksnius bei jų atsiradimą po ortodontinio gydymo. A. Renkema ir kt. bei J. Juloski ir kt. atliktų klinikinių studijų duomenimis, dantenų recesijų atsiradimo dažnumas tiesiogiai susijęs su laiko tarpu, praejjusiu po ortodontinio gydymo $[13,14]$. Skirtingi autoriai klinikinèse studijose nurodo skirtingą dantenų recesijų paplitimo procentą pagal metus, praejusius po ortondontinio gydymo. Šiuos skirtumus galëjo lemti nevienoda klinikinių studijų stebejjimo (angl. follow up) trukmé: pateikiami rezultatai po 5 , po 8 ir po 13 metų, baigus ortodontini gydymą $[13,15,16]$. Autorių gautų rezultatų skirtumus galèjo lemti ir skirtingi dantenų atsitraukimo vertinimo būdai (gipsiniai modeliai bei klinikinis ištyrimas), skirtingų dantų grupių vertinimas (J. Juloski ir kt. nurodo, jog recesijų dažnis didesnis iltinių sijų lingvaliniame paviršiuje. Autoriai pateikè išvadas, jog 
dantų srityje, o F. Pernet ir kt. duomenimis - apatinių kandžių bukaliniame paviršiuje $[12,14]$ ) bei nekontroliuojami veiksniai, tokie kaip individualūs pacientų ịpročiai, burnos higienos ịgūdžiai, mityba ir kt.) [16]. Skirtingą dantenų atsitraukimo dažnį tarp skirtingų dantų grupių gali lemti pradinè netaisyklinga dantų padètis lanke, netaisyklingi dantų valymo judesiai, kieto dantų šepetèlio naudojimas [12].

A. Renkema ir kt., F. Pernet ir kt. nurodo, jog skirtingą recesijų paplitimo dažni gali sąlygoti ir reteinerio tipas: remiantis gautais rezultatais, didesnè recesijų tikimybė yra fiksuotą reteinerị dèvintiems pacientams $[12,13]$. Priešingus rezultatus gavo J. Juloski ir bendraautoriai, kurių klinikinès studijos rezultatai nenurode statistiškai reikšmingo skirtumo tarp recesijų atsiradimo ir fiksuotų ortodontinių reteinerių dèvejjimo [14]. Autorių duomenimis, fiksuoti ortodontiniai reteineriai lemia didesnį konkrementų kaupimąsi, bet ne dantenų atsitraukimą. Tokie rezultatai galèjo būti gauti dèl to, jog ị klinikinę studiją įtraukti tik ortodontiškai gydyti pacientai, o kontrolinės grupés, t.y. ortodontiškai negydytų pacientų, nebuvo [14].

A. Renkema ir kiti autoriai nustate, jog lytis nedaro poveikio dantenų atsitraukimui $[13,17,18]$. Kontraversiškus rezultatus gavo F. Pernet ir bendraautoriai, kurių rezultatai rodo didesnį dantenų recesijų paplitimą tarp vyrų, lyginant su moterimis [12]. Skirtingi rezultatai galèjo būti dèl didelio amžiaus nuokrypio tarp tiriamụjų grupių skirtingose klinikinèse studijose. Dél šios priežasties reikalingos išsamesnès klinikinès studijos, kad galima būtu priimti arba paneigti hipotezę, jog lytis daro poveikį dantenų atsitraukimui.

Nors nuomoné dèl ortodontinio gydymo poveikio dantenų recesijai yra kontraversiška, skirtingi autoriai bendrai sutinka, jog prieš pradedant ortodontini gydymą, reikia ịvertinti paciento amžių, minkštujų audinių biotipą, alveolinès ataugos kaulo tankumą, kraštinių dantenų padèti, nes tai gali lemti dantenų recesijų atsiradimą. Vadovaujantis surinkta anamneze, galima individualiai suplanuoti ortodontinio gydymo metu taikomus danties judesius [13,14,19].

Siekiant patvirtinti ar paneigti gautus rezultatus, reikalingos tolesnès, didesnès imties, ilgesnio stebejjimo periodo klinikinès studijos. Siekiant gauti patikimesnius rezultatus, reikalingos kontroliuojamos klinikinės studijos, vertinančios ne tik sąkandžio anomalijas bei apnašų indeksus, bet ir apydančio audinių būklę, ypač dantenų biotipą bei alveolinès ataugos kaulo storị.

\section{Išvados}

1. Laikas po ortodontinio gydymo turi poveikị dantenų recesijos formavimosi dažniui: kuo daugiau laiko po ortodontinio gydymo, tuo didesnei pacientų daliai atsiranda dantenų recesija.
2. Amžiaus ir lyties sąsaja dantenų recesijos formavimosi dažniui išlieka neaiški.

\section{Literatūra}

1. Bai YX. Risk perception and management in orthodontic treatment. Chin J Stomatol 2019;54(12):793-797.

2. Benson PE, Javidi H, DiBiase AT. What is the value of orthodontic treatment? Br Dent J 2015;218(3):185-90.

https://doi.org/10.1038/sj.bdj.2015.43

3. Christensen L, Luther F. Adults seeking orthodontic treatment: expectations, periodontal and TMD issues. Br Dent J 2015; 218(3):111-117.

https://doi.org/10.1038/sj.bdj.2015.46

4. Antezack A, Monnet-Corti V. Oral and periodontal hygiene in orthodontic patients. Orthod Fr 2018;89(2):181-190.

https://doi.org/10.1051/orthodfr/2018015

5. Merijohn GK. Management and prevention of gingival recession. Periodontology 2000 2016;71(1):228-242.

https://doi.org/10.1111/prd.12115

6. Jati AS, Furquim LZ, Consolaro A. Gingival recession: its causes and types, and the importance of orthodontic treatment. Dental Press J Orthod 2016;21(3):18-29.

https://doi.org/10.1590/2177-6709.21.3.018-029.oin

7. Cortellini P, Bissada NF. Mucogingival conditions in the natural dentition: narrative review, case definitions, and diagnostic considerations. J Periodontol 2018;89(1)204-213.

https://doi.org/10.1002/JPER.16-0671

8. Melsen B, Allais D. Factors of importance for the development of dehiscences during labial movement of mandibular incisors: a retrospective study of adult orthodontic patients. Am J Orthod Dentofacial Orthop 2005;127(5):552-61.

https://doi.org/10.1016/j.ajodo.2003.12.026

9. Ji JJ, Li XD, Fan Q, Liu XJ, Yao S, Zhou Z, Yang S, ShenY. Prevalence of gingival recession after orthodontic treatment of infraversion and open bite. J Orofac Orthop 2019;80(1):1-8.

https://doi.org/10.1007/s00056-018-0159-8

10. Morris JW, Campbell PM, Tadlock LP, Boley J, Buschang PH. Prevalence of gingival recession after orthodontic tooth movements. Am J Orthod Dentofacial Orthop 2017;151(5):851-859. https://doi.org/10.1016/j.ajodo.2016.09.027

11. American association of orthodontists. Why strengthen teeth? St. Louis: American Association Orthodontists 2016.

12. Pernet F, Vento C, Pandis N, Kiliaridis S. Long-term evaluation of lower incisors gingival recessions after orthodontic treatment. European Journal Orthodontics 2019; 41(6):559-564. https://doi.org/10.1093/ejo/cjy086

13. Renkema AM, Fudalej PS, Renkema A, Kiekens R, Katsaros C. Development of labial gingival recessions in orthodontically treated patients. Am J Orthod Dentofacial Orthop 2013;143(2):206-12.

https://doi.org/10.1016/j.ajodo.2012.09.018 
14. Juloski J, Glisic B, Vandevska-Radunovic V. Long-term influence of fixed lingual retainers on the development of gingival recession: a retrospective, longitudinal cohort study. Angle Orthod 2017;87(5):658-664.

https://doi.org/10.2319/012217-58.1

15. Thomson WM. Orthodontic treatment outcomes in the long term: findings from a longitudinal study of New Zealanders. Angle Orthod 2002;72:449-55.

16. Vasconcelos G, Kjellsen K, Preus H, Vandevska-Radunovic V, Hansen BF. Prevalence and severity of vestibular recession in mandibular incisors after orthodontic treatment. Angle Orthod 2012;82(1):42-7. https://doi.org/10.2319/021411-108.1

17. Ainamo J, Paloheimo L, Nordblad A, Murtomaa H. Gingival recession in schoolchildren at 7, 12 and 17 years of age in Espoo, Finland. Community Dent Oral Epidemiol 1986;14(5):283-6. https://doi.org/10.1111/j.1600-0528.1986.tb01073.x

18. Susin C, Haas AN, Oppermann RV, Haugejorden O, Albandar JM. Gingival recession: epidemiology and risk indicators in a representative urban Brazilian population. J Periodontol 2004;75(10):1377-86. https://doi.org/10.1902/jop.2004.75.10.1377

19. Johal A, Katsaros C, Kiliaridis S, Leitao P, Rosa M, Sculean A, Weiland F, Zachrisson B. State of the science on controversial topics: orthodontic therapy and gingival recession (a report of the angle society of Europe 2013 meeting). Prog Orthod 2013;14(1):16.

https://doi.org/10.1186/2196-1042-14-16

\section{THE IMPACT OF ORTHODONTIC TREATMENT ON}

GINGIVAL RECESSION FORMATION

D. Grinkevičienė, U.M. Sakalauskaitė, A. Antipovienė

Keywords: gingival recession, orthodontic treatment.

\section{Summary}

Relevance of the research problem. Gingival recession is one of the most common complications occurring after orthodontic treatment. The mechanism and aetiology of gingival recession formation are incompletely understood and thought to be multifactorial in nature, with predisposing and precipitating factors implicated: poor oral hygiene, orthodontic forces, thin buccal mucosa, etc. Controversy exists regarding the relationship between orthodontic treatment and gingival recession in the medical literature. Movement of teeth outside the alveolar bone has been reported as a risk factor for gingival recession, other authors have found no such association.

Materials and methods. This literature review has been carried out in accordance with the PRISMA. Electronic literature review has been based on selection criteria and performed using MEDLINE as well as COCHRANE databases.

Results. This literature review includes 3 scientific publications which fully met the requirements.

Conclusions. According to this literature review, there is a strong relation between the gingival recession formation and the period following orthodontic treatment: the likelihood of gingival recession development increases each following year after the end of orthodontic treatment. Also, several authors conclude that the age of the patient is important for the occurrence of gingival recession.

Correspondence to: dominyka.narb@gmail.com

Gauta 2020-02-20 